\title{
Pemetaan Kelas Kesesuaian Lahan Untuk Budidaya Tambak dengan Metode Skoring
}

\author{
Radhi Ariawan ${ }^{1}$, Arfita Rahmawati ${ }^{2}$ \\ ${ }^{1}$ Program Studi Teknik Mesin, Politeknik Negeri Cilacap \\ ${ }^{2}$ Program Studi Pendidikan Geografi, Universitas Nusa Cendana \\ ${ }^{1} J 1 n$. Dr. Soetomo No.1 Karangcengis Sidakaya, Kabupaten Cilacap, 53212, Indonesia \\ ${ }^{2}$ Jl. Laksda Adi Sucipto, Penfui, Kota Kupang, 85001, Indonesia \\ E-mail: radhi.ariawan@pnc.ac.id ${ }^{1}$, arfitarahmawati@staf.undana.ac.id ${ }^{2}$
}

\section{Info Naskah:}

Naskah masuk: 29 Mei 2021

Direvisi: 16 Agustus 2021

Diterima: 20 Agustus 2021

\begin{abstract}
Abstrak
Budidaya tambak merupakan potensi di bidang pesisir yang ada di Kecamatan Nusawungu. Untuk mengoptimalkan potensi tambak ikan dan udang di Kecamatan Nusawungu, maka dilakukan pemetaan terhadap lokasi pesisir yang cocok sebagai kawasan budidaya tambak. Penelitian ini termasuk dalam penelitian deskriptifkuantitatif tentang kelas kesesuaian lahan budidaya tambak dengan metode skoring dari hasil overlay parameter penggunaan lahan, jenis tanah, tekstur tanah, kemiringan lereng, jarak dari sungai, dan jarak dari pantai. Kelas kesesuaian lahan berdasar metode ini dibagi dalam 3 (tiga) kelas, yaitu sesuai (S1), sesuai bersayarat (S2), dan tidak sesuai (S3). Hasil penelitian menunjukan sebesar 48,32\% atau seluas 29,6008 $\mathrm{km}^{2}$, termasuk dalam kategori S1 (sesuai) sebagai lokasi untuk budidaya tambak. Selanjutnya tercatat kelas S2 (sesuai bersyarat) untuk wilayah sebesar 33,98\% atau seluas 20,8039 $\mathrm{km}^{2}$. Kelas S3 (tidak sesuai) tercatat sebesar $17,72 \%$ atau seluas $10,8553 \mathrm{~km}^{2}$
\end{abstract}

\section{Keywords:}

pond cultivation;

scoring;

land suitability class.

\begin{abstract}
Pond cultivation is a coastal sector's potential in Nusawungu District. To optimize the potential of fish and shrimp ponds in Nusawungu District, mapping of the suitable coastal locations as pond cultivation areas was carried out. This research was included in descriptive - quantitative study of the suitability class of pond cultivation land by using the scoring method from the overlay parameter of land usage, soil type, soil texture, slope inclination, pond to river distance, and pond to beach distance. The land suitability class based on this method was divided into 3 (three) classes, suitable (S1), conditionally suitable (S2), and unsuitable (S3). The results showed that $48.32 \%$ or an area of $29.6008 \mathrm{~km}^{2}$, categorized $\mathrm{S} 1$ (suitable) as location for pond cultivation. Furthermore, the S2 (Conditionally suitable) class was recorded for $33.98 \%$ or an area of $20.8039 \mathrm{~km}^{2}$. S3 (unsuitable) class was recorded for $17.72 \%$ or an area of 10.8553 $\mathrm{km}^{2}$.
\end{abstract}

\section{*Penulis korespondensi:}




\section{Pendahuluan}

Negara Indonesia terdiri dari 17.504 pulau, dimana dua pertiga wilayahnya merupakan perairan atau laut[1]. Panjang garis pantai yang dimiliki Indonesia menempati urutan ke-4 di dunia yaitu $99.093 \mathrm{~km} \mathrm{[2].} \mathrm{Hal} \mathrm{ini}$ menyebabkan sumber daya laut memainkan peran penting bagi perekonomian Indonesia. Indonesia merupakan salah satu produsen perikanan budidaya terbesar di dunia [3]. Salah satu potensi sumberdaya laut Indonesia dalam hal ini adalah budidaya tambak.

Pembangunan budidaya tambak di Pulau Jawa sebagian besar di arahkan pada bagian selatan [4]. Salah satu kabupaten yang terletak di bagian selatan Pulau Jawa adalah Kabupaten Cilacap. Luas tambak di Kabupaten Cilacap pada tahun 2018 sebesar 1.183,21 hektar [5]. Salah satu kecamatan di Kabupaten Cilacap adalah Kecamatan Nusawungu. Kecamatan Nusawungu terletak di bagian barat Kabupatem Cilapacap. Berdasarkan data Badan Pusat Statistik (BPS) Tahun 2018 diketahui luas tambak ikan dan udang di Kecamatan Nusawungu sebesar 40,78 hektar dengan hasil produksi $1.618 .211,00 \mathrm{~kg}$.

Untuk pengoptimalisasi potensi tambak ikan dan udang di Kecamatan Nusawungu maka perlu dilakukan pemetaan terhadap lokasi (terutama pesisir) yang cocok sebagai kawasan budidaya tambak. Dengan kata lain fungsi dari pemetaan ini untuk memetakan wilayah di Kecamatan Nusawungu yang cocok digunakan untuk budidaya tambak. Peta adalah alat bantu yang baik untuk kepentingan melaporkan, memperagakan, menganalisis dan secara umum untuk memahami suatu objek atau kenampakan di muka bumi [6]. Peta dapat digunakan sebagai alat yang baik untuk kepentingan: melaporkan, memperagakan, menganalisis, dan secara umum untuk pemahaman saling hubungan dari benda-benda secara keruangan [7].

Pembuatan peta kesesuaian lahan budidaya tambak di Kecamatan Nusawungu menggunakan sistem informasi geografis dengan teknik analisa skoring. Sistem Informasi Geografis (SIG) adalah suatu sistem informasi yang berbasis komputer, dirancang untuk bekerja dengan menggunakan data yang memiliki informasi tentang suatu spasial (referensi spasial) [8]. Kemudian untuk skoring digunakan parameter: penggunaan lahan, jenis tanah, tekstur tanah, kemiringan lereng, jarak dari sungai, dan jarak dari pantai. Parameter penggunaan lahan, sungai, dan paintai didapatkan dari data landsat 8 OLI. Landsat 8 OLI digunakan karena dibandingkan dengan sensor satelit resolusi menengah dan rendah (misalnya MODIS dan citra spektroradiometer resolusi sedang), memiliki informasi spasial yang lebih baik dengan resolusi spasialnya yang tinggi yaitu 30m [9]. Kemiringan lereng didapatkan dari data DEM Kecamatan Nusawungu yang kemudian diklasifikasikan dengan klasifikasi van zuidam. Jenis Tanah diketahui dengan menggunakan peta jenis tanah dari FAO. Terkait tekstur tanah diketahui dari hasil pengambilan sampel di lapangan dengan menggunakan 17 titik pengambilan sampel. Pembagian kelas skoring terbagi menjadi 3 kelas, yaitu sesuai (S1), sesuai bersyarat (S2), dan tidak sesuai (S3). Sehingga dihasilkan peta kelas kesesuaian lahan yang dapat digunakan oleh pemerintah untuk masukan dalam pembangunan wilayah pesisir di Kecamatan Nusawungu terutama dalam. sektor budidaya tambak.

Penelitian sebelumnya oleh Krisna [10] mengenai analisis kesesuaian lahan tambak terhadap produktivitas budidaya udang menggunakan SIG (Studi Kasus : Kabupaten Kendal menggunakan parameter kualitas air, jarak ke pantai, jarak ke sungai, kelerengan, dan jenis tanah. Penelitian lain dilakukan oleh Budi [11] terkait sistem informasi geografis pemetaan lokasi budidaya tambak ikan di Dinas Perikanan dan Kelautan Kabupaten Langkat menggunakan metode clustering menggunakan parameter lokasi tambak dan penggunaan lahan. Kemudian penelitian oleh Fauzi [12] dengan studi pemetaan kawasan tambak Kecamatan Sinjai Timur dengan menggunakan penginderaan jauh dan sistem informasi geografis, parameter yang digunakan adalah parameter penggunaan lahan. Selain itu penelitian yang dilakukan oleh Mostafa Abbasi di tahun 2020 yang berjudul menggunakan parameter ketinggian, kemiringan lereng, kemampuan penggunaan lahan, tutupan lahan, dan suhu rata-rata dalam penentuan kesesuaian lahan dengan analisis overlay 5 ksesuaian [13].

Berbeda dengn penelitian sebelumnya, pada penelitian untuk penelitian ini menggunakan parameter penggunaan lahan, jenis tanah, tekstur tanah, kemiringan lereng, jarak dari sungai, dan jarak dari pantai dengan menggunakan analisis overlay dengan 3 kelas kesesuaian lahan dalam budidaya tambak.

\section{Metode}

Studi ini termasuk dalam penelitian deskriptif kuantitatif tentang kelas kesesuaian lahan budidaya tambak yang berlokasi di Kecamatan Nusawungu. Populasi yang digunakan adalah populasi keruangan, yaitu Kecamatan Nusawungu. Sampel dalam penelitian ini menggunakan sampel jenuh. Sampel jenuh merupakan teknik pengambilan sampel yang semua populasi dijadikan sampel [14]. Penelitian ini menggunakan sistem informasi geografis dengan analisis skoring dari hasil overlay parameter penggunaan lahan, jenis tanah, tekstur tanah, kemiringan lereng, jarak dari sungai, dan jarak dari pantai. 


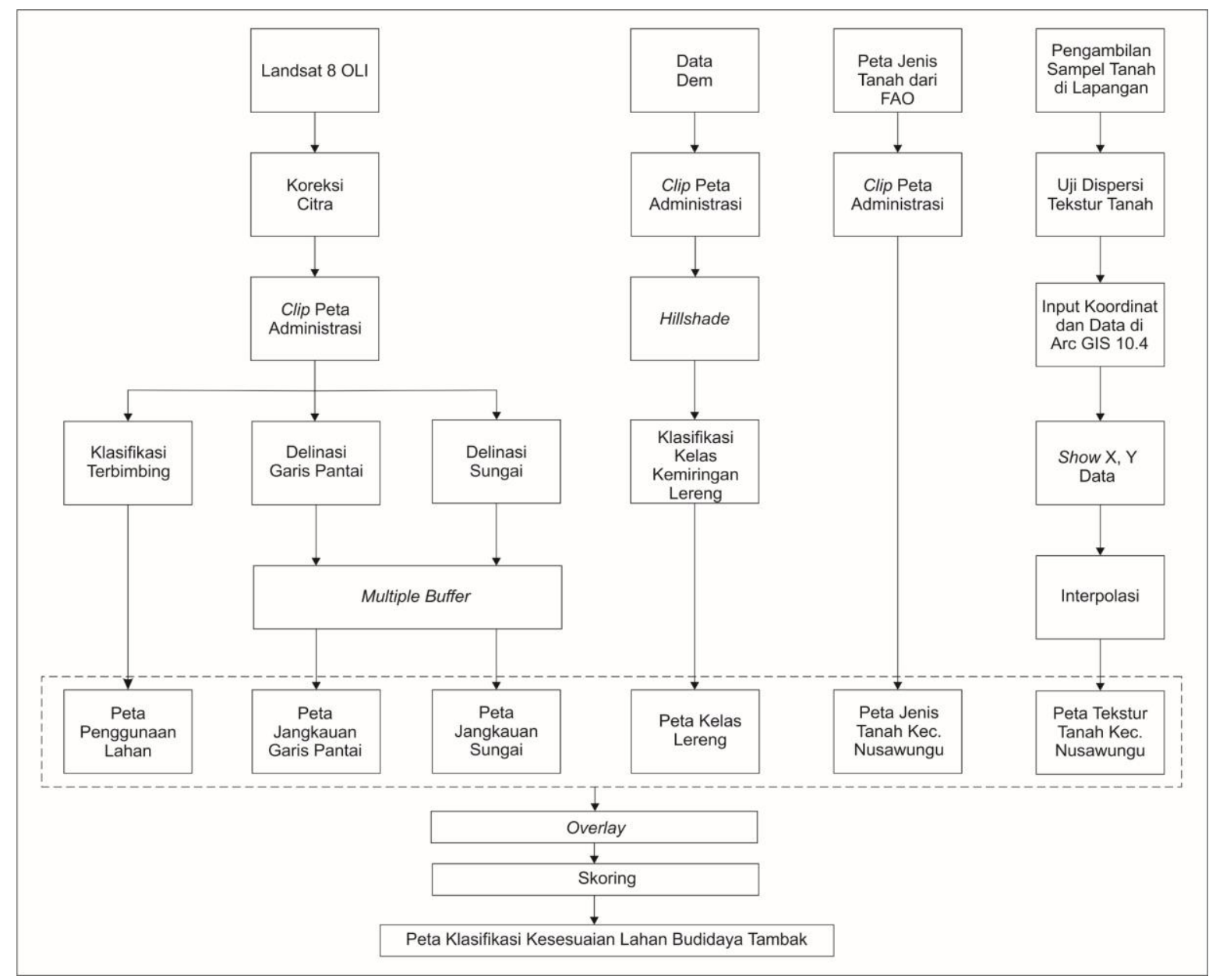

Gambar 1. Diagram Alur Penelitian

Pada Gambar 1 menunjukkan diagram alir penelitian yang mana, untuk pengolahan parameter penggunaan lahan digunakan data dari landsat 8 OLI yang dikoreksi terlebih dahulu kemudian dilakukan analisis klasifikasi terbimbing dengan menggunakan ENVI. Jenis tanah didapatkan dari peta jenis tanah dunia dari FAO yang dilakukan clip atau pemotongan dengan peta administrasi Kecamatan Nusawungu. Tekstur tanah didapatkan dengan pengambilan sampel di lapagan kemudian dilakukan pengukuran analisis tekstur tanah dengan metode dispersi. Metode dispersi adalah gabungan dari gerakan gerakan molekuler dan turbulen, dibantu oleh proses-proses yang memperbesar volume yang ditempati dan sehingga meningkatkan kontak area di mana proses percampuran berlangsung [15].

Setelah dilakukan dispersi kemudian dihitung persentase tanah, liat, dan debu untuk dimasukan ke dalam segitiga tekstur, selanjutnya dilakukan interpolasi dengan menggunakan ARC GIS 10.4. Kemiringan lereng didapatkan dari hasil pengolahan data DEM Kecamatan Nusawungu selanjutnya diolah dengan ARC GIS 10.4 dengan analisis hillshade dan dilakukan pengelompokan kelas kemiringan lereng berdasarkan klasifikasi van zuidam. Parameter jarak dari sungai dan pantai didapatkan dari data digitasi landsat 8 OLI kemudian dilakukan clip dengan peta administrasi kemudian dianalisis menggunakan multiplebuffer. Setelah semua parameter siap, selanjutnya dilakukan overlay seluruh parameter dan dilakukan skoring untuk selanjutnya dibagi ke dalam 3 (tiga) kelas kesesuaian lahan, yaitu sesuai (S1), sesuai bersyarat (S2), dan tidak sesuai (S3).

\section{Hasil dan Pembahasan.}

Pada Kelas Kesesuaian Lahan Budidaya Tambak, pertama-tama dilakukan analisis pada masing masing parameter. Untuk parameter penggunaan lahan didapatkan dari citra landsat 8 OLI tahun 2020 yang selanjutnya dilakukan klasifikasi terbimbing.

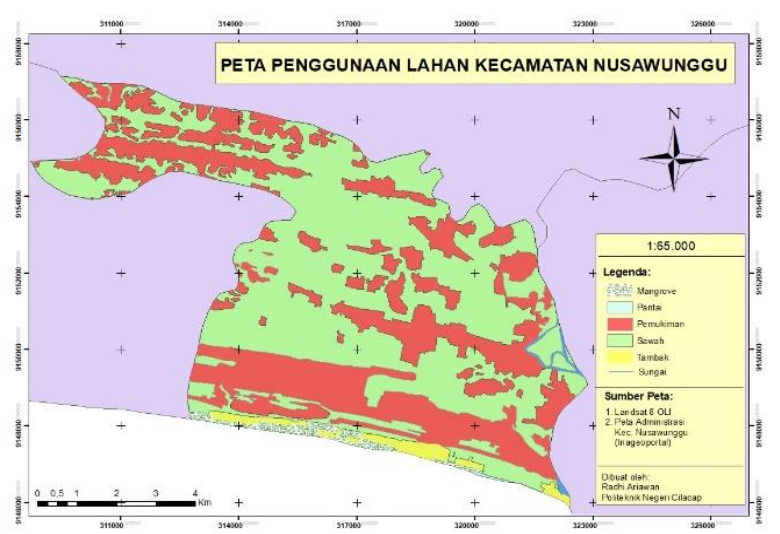

Gambar 2. Peta Penggunaan Lahan 
Dapat dilihat dalam gambar 2 sebagian besar penggunaan lahan di Kecamatan Nusawungu berupa sawah. Setelah dilakukan analisis terhadap parameter penggunaan lahan, yaitu melakukan deliniasi terhadap parameter garis pantai dan sungai. Kemudian dilakukan analisis menggunakan multiple ring buffer. Untuk garis pantai jarak yang digunakan seperti pada Gambar 3. Dalam penentuan jarak dalam gambar 3 digunakan jarak dari pantai sejauh 2000m, 3000m, dan 4000m [16]. Sedangkan untuk jarak dari sungai menggunakan jarak 500 m, 1000 m, dan 1500 $\mathrm{m}$, asilnya seperti pada Gambar 4. Dalam pembuatan peta jenis tanah digunakan data dari FAO yang kemudian dilakukan clip terhadap shapefile administrasi Kecamatan Nusawungu, seperti pada Gambar 5.

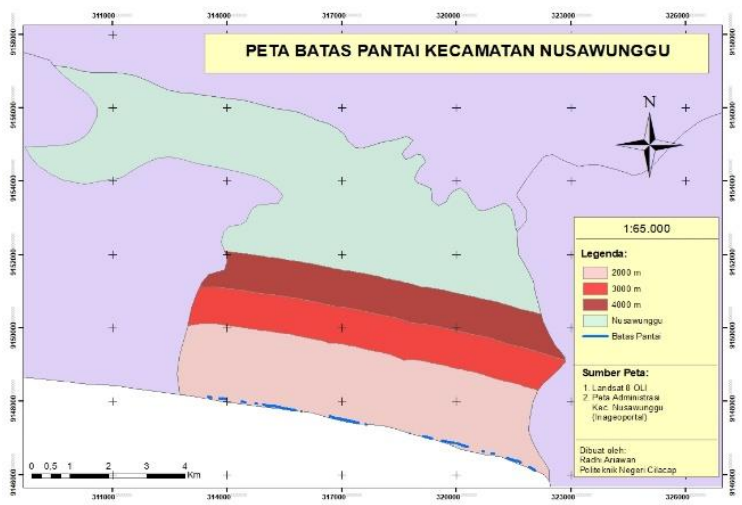

Gambar 3. Peta Batas Pantai

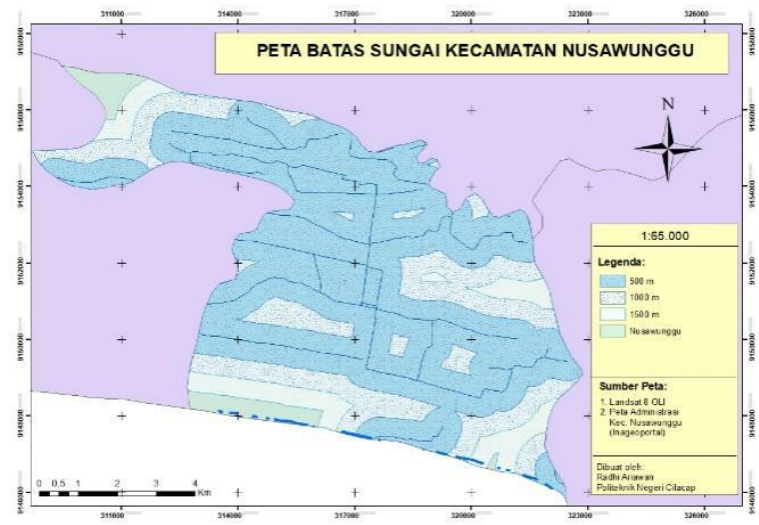

Gambar 4. Peta Batas Sungai

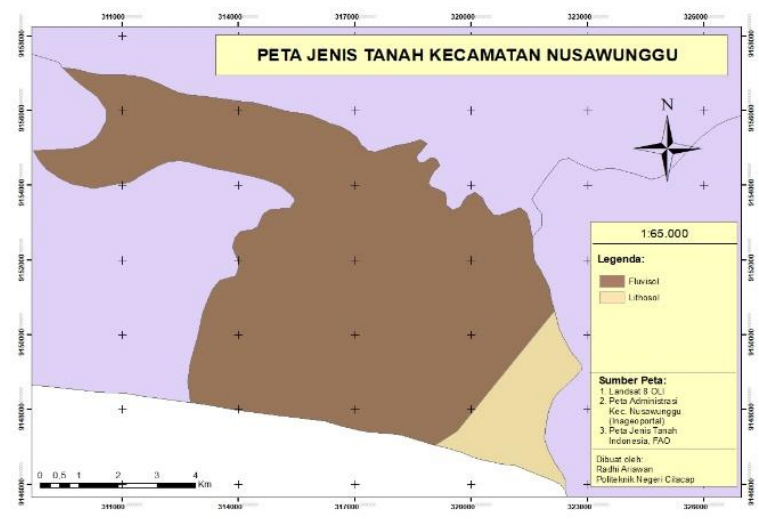

Gambar 5. Peta Jenis Tanah
Berdasarkan gambar 5 diketahui jenis tanah yang ada di Kecamatan Nusawungu adalah jenis tanah Fluvisol dan Lithosol. Untuk melakukan analisis tekstur tanah digunakan pengambilan sampel tanah di masing-masing desa yang terdapat di Kecamatan Nusawungu. Kemudian dilakukan metode disperse untuk mengetahui tekstur tanah pada masing-masing sampel yang sudah diambil. Selanjutnya hasil dari metode disperse tersebut dimasukan ke dalam tabel field titik pengambilan sampel untuk dilakukan interpolasi, sehingga dihasilkan peta tekstur tanah.
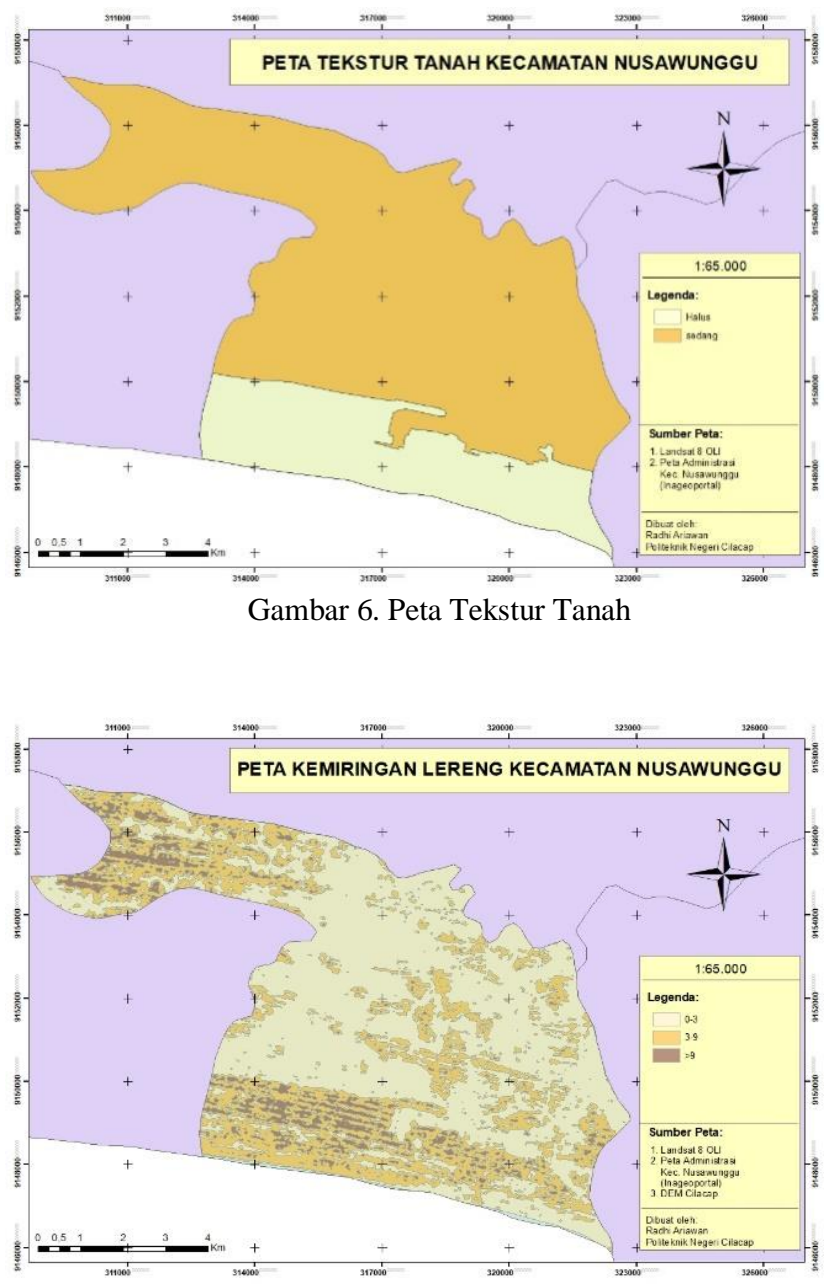

Gambar 7. Peta Kemiringan Lereng

Gambar 6 menunjukkan tekstur tanah yang terdapat di Kecamatan Nusawungu adalah halus dan sedang. Untuk penentuan kemiringan lereng didapatkan data dari DEM Kecamatan Nusawungu dengan pembagian persentase kemiringan lereng berdasarkan Van Zuidam. Selanjutnya dilakukan overlay parameter penggunaan lahan, batas pantai, batas sungai, jenis tanah, tekstur tanah, dan kemiringan lereng dengan metode skoring berdasarkan Tabel 1.

Dari tabel skoring pada Tabel 1, dibuat skoring pembagian kelas kesesuaian lahan seperti pada Tabel 2. 
Tabel 1. Nilai Skoring Tiap-Tiap Parameter

\begin{tabular}{llc}
\hline \multicolumn{1}{c}{ Parameter } & \multicolumn{1}{c}{ Kriteria } & Skor \\
\hline $\begin{array}{l}\text { Penggunaan } \\
\text { Lahan }\end{array}$ & $\begin{array}{l}\text { Sawah, tambak, } \\
\text { tegalan, belukar, } \\
\text { hutan pantai }\end{array}$ & 3 \\
& $\begin{array}{l}\text { Kebun, hutan } \\
\text { rawa }\end{array}$ & 2 \\
& Pemukiman & 1 \\
Batas Pantai & $<2000 \mathrm{~m}$ & 3 \\
& $2000-3000 \mathrm{~m}$ & 2 \\
& $3000-4000 \mathrm{~m}$ & 1 \\
Batas Sungai & atau $>4000 \mathrm{~m}$ & \\
& $<500 \mathrm{~m}$ & 3 \\
& $500-1000 \mathrm{~m}$ & 2 \\
Jenis Tanah & $1000-1500 \mathrm{~m}$ & 1 \\
& atau $>1500 \mathrm{~m}$ & \\
& Alluvial, Fluvisol & 3 \\
Hitolol, andosol, & 2 \\
Tekstur Tanah & Lithosol & \\
& Regosol & 1 \\
Halus & 3 \\
Kemiringan & Sedang & 2 \\
Kereng & Kasar & 3 \\
& $0-3 \%$ & 2 \\
& $3-9 \%$ & 1 \\
\hline
\end{tabular}

Tabel 2. Skoring Kelas Kesesuaian Lahan Budidaya Tambak

\begin{tabular}{lc}
\multicolumn{1}{c}{ Kelas } & Skor \\
\hline S1 (sesuai) & $13-18$ \\
S2 (sesuai bersyarat) & $7-12$ \\
S3 (tidak sesuai) & $0-6$ \\
\hline
\end{tabular}

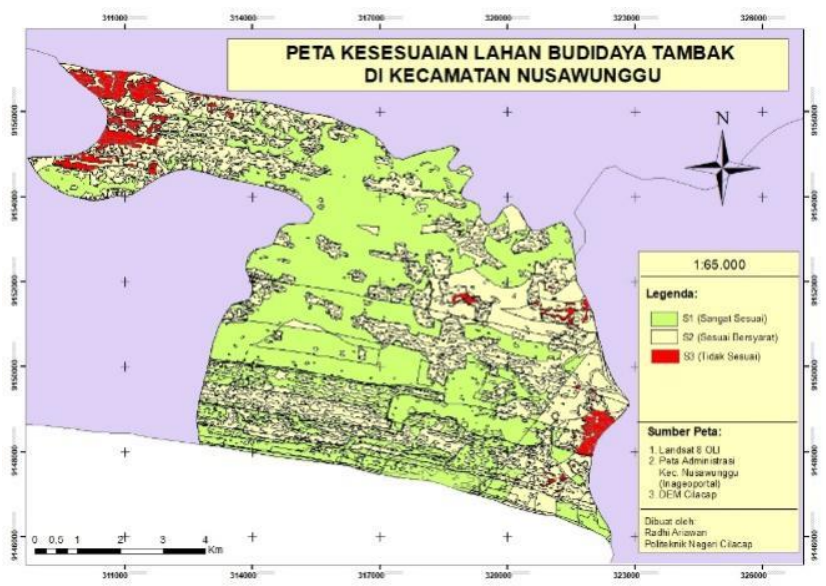

Gambar 8. Peta Kesesuaian Lahan Budidaya Tambak

Kemudian setelah dilakukan overlay kemudian dikelompokan berdasarkan nilai skoring kelas kesesuaian lahan budidaya tambak dengan pembagian 3 kelas yaitu $\mathrm{S} 1$, S2, dan S3, dihasilkan peta kesesuaian lahan budidaya tambak di Kecamatan Nusawungu seperti pada Gambar 8.

Selanjutnya dihitung persentase luasan kesesuaian lahan dengan menggunakan geometry field, hasilnya diperlihatkan pada Tabel 3.
Tabel 3. Luasan Kesesuaian Lahan Budidaya Tambak di

\begin{tabular}{lcc}
\multicolumn{3}{c}{ Kecamatan Nusawungu } \\
\hline \multicolumn{1}{c}{ Kelas } & Luas $\left(\mathbf{K m}^{\mathbf{2}}\right)$ & Persentase (\%) \\
\hline S1 (sesuai) & 29,6008 & 48,32 \\
\hline $\begin{array}{l}\text { S2 } \\
\text { (sesuai bersyarat) }\end{array}$ & 20,8039 & 33,96 \\
\hline $\begin{array}{l}\text { S3 } \\
\text { (tidak sesuai) }\end{array}$ & 10,8553 & 17,72 \\
\hline
\end{tabular}

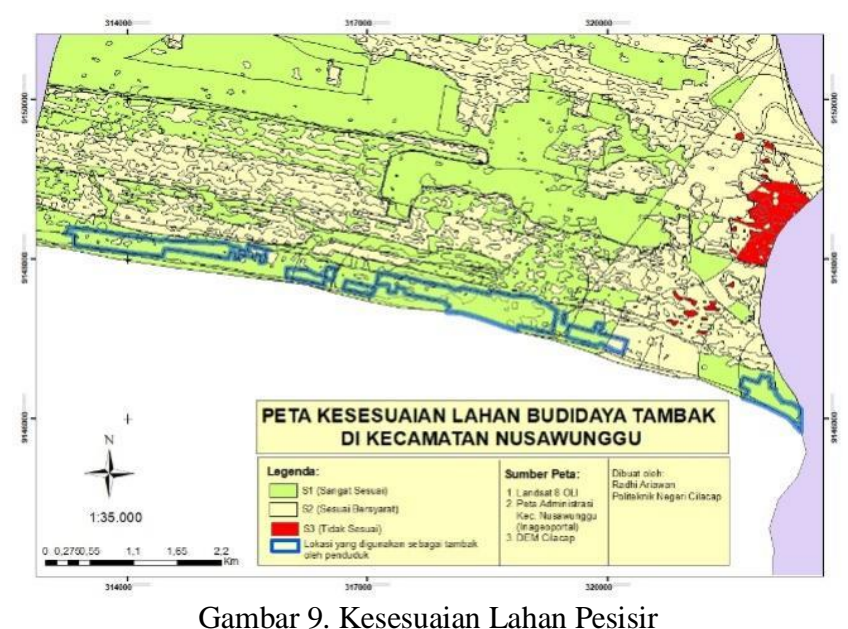

Tabel 4. Luasan Kesesuaian Lahan Budidaya Tambak Berdasarkan Tambak yang Sudah Ada Tahun 2020

\begin{tabular}{lcc}
\hline \multicolumn{1}{c}{ Kelas } & Luas $\left.\mathbf{( K m}^{2}\right)$ & Persentase (\%) \\
\hline S1 (sesuai) & 0,49972 & 78,35 \\
S2 (sesuai bersyarat) & 0,13808 & 21,65 \\
S3 (tidak sesuai) & 0 & 0 \\
\hline
\end{tabular}

Dari Tabel 3 dapat diamati bahwa sebesar 48,32\% atau dengan luas 29,6008 $\mathrm{km}^{2}$, Kecamatan Nusawungu termasuk dalam kategori S1 (sesuai) sebagai lokasi untuk budidaya tambak. Sedangkan kelas S2 (sesuai bersyarat) untuk Kecamatan Nusawungu seluas 33,98\% atau 20,8039 $\mathrm{km}^{2}$. Kelas S3 (tidak sesuai) seluas $17,72 \%$ atau 10,8553 $\mathrm{km}^{2}$. Untuk kesesuaian daerah pesisir dapat dilihat pada Gambar 9.

Dari gambar 9 terlihat untuk wilauah pesisir terdapat pula kelas kesesuaian S2 (sesuai bersyarat). Untuk gambar dengan garis biru pada gambar 9 merupakan lokasi tambak yang ada di Kecamatan Nusawungu tahun 2020. Dilihat berdasarkan kelas kesesuaian lahannya, tambak yang ada di Kecamatan Nusawungu terbagi seperti pada Tabel 4.

Luas tambak di Kecamatan Nusawungu berdasar pada Citra Landsat 8 Oli tahun 2020 seluas $0,6378 \mathrm{~km}^{2}$ atau seluas 63,78 hektar. Senbesar 78,35 \% termasuk dalam kelas kesesuaian lahan S1 (sesuai) untuk budidaya tambak. Sedangkan sebesar $21,65 \%$ termasuk dalam kelas S2 (sesuai bersyarat). 


\section{Kesimpulan}

Kecamatan Nusawunggu memiliki persentase kesesuaian lahan 48,32\% atau luas $29,6008 \mathrm{~km}^{2}$ termasuk dalam kategori cocok sebagai budidaya tambak. Pada beberapa wilayah pesisir dan lokasi yang sudah digunakan masyarakat Kecamatan Nusawungu sebagai tambak termasuk ke dalam lokasi dengan kriteria kelas kesesuaan S2 (sesuai bersyarat) sehingga dalam pengelolaan pesisir terutama yang berada di kelas S2 perlu dilakukan pengolahan lebih lanjut atau perlakuan khusus terhadap lahan tersebut jika ingin digunakan sebagai lokasi budidaya tambak.

\section{Daftar Pustaka}

[1] Y. Listiyono, L. Y. Prakoso, and D. Sianturi, "Membangun kekuatan laut indonesia dipandang dari pengawal laut dan detterence effect indonesia building indonesian sea power based on the indonesian sea guard and detterent effect," Strateg. Pertahanan Laut, vol. 5, no. 1, pp. 73-84, 2019.

[2] E. Sulistyowati, M. A. Masnun, A. Nugroho, N. Hikmah, and M. Wardhana, "Penerapan Perjanjian bagi Hasil terhadap Pengelolaan Bersama Lahan Budidaya Tambak di Kabupaten Gresik," J. Cakrawala Huk., vol. 10, no. 2, pp. 187-197, 2019, doi: 10.26905/idjch.v10i2.3365.

[3] P. Senff, S. Partelow, L. F. Indriana, N. Buhari, and A. Kunzmann, "Improving pond aquaculture production on Lombok, Indonesia," Aquaculture, vol. 497, pp. 64-73, Dec. 2018, doi: 10.1016/j.aquaculture.2018.07.027.

[4] A. I. Choeronawati, S. B. Prayitno, and . Haeruddin, "Studi Kelayakan Budidaya Tambak Di Lahan Pesisir Kabupaten Purworejo," J. Ilmu dan Teknol. Kelaut. Trop., vol. 11, no. 1, pp. 191-204, 2019, doi: 10.29244/jitkt.v11i1.22522.

[5] BPS, Data Luas Tambak 2018. Cilacap: Badan Pusat Statistik, 2018

[6] O. Nurdiawan, H. Putri, P. Studi, and T. Informasi, "Pemetaan daerah rawan banjir berbasis sistem informasi geografis dalam upaya mengoptimalkan langkah antisipasi bencana," J. Infotech, vol. 4, no. 2, pp. 1-9, 2018.

[7] D. A. Punuf, A. Rahmawati, B. Theo, and T. Pamungkas, "Pemetaan Kawasan Hutan Mangrove di Teluk Kupang dengan Teknologi Penginderaan Jauh dan Sistem Informasi
Geografi," Pendidik. Geogr., vol. 16, no. 2, Desember 2020, pp. 15-21, 2020.

[8] P. Dewa, B. Mulyanti, and I. Widiaty, "Geographic information system in education," IOP Conf. Ser. Mater. Sci. Eng., vol. 830, no. 042097, pp. 1-4, 2020, doi: $10.1088 / 1757-899 X / 830 / 4 / 042097$.

[9] S. A. L. Dian Wang, Ronghua Ma, Kun Xue, "The Assessment of Landsat-8 OLI Atmospheric Correction Algorithms for Inland Waters," Remote Sens., vol. 11, no. 169, pp. 1-23, 2019.

[10] H. S. F. Krisna Setiaji, Arief Laila Nugraha, "Analisis Kesesuaian Lahan Tambak Terhadap Produktivitas Budidaya Udang Menggunakan Sig (Studi Kasus : Kabupaten Kendal)," J. Geod. Undip, vol. 7, no. 4, pp. 128137, 2018.

[11] B. S. Ginting and R. Kurniawan, "Sistem Informasi Geografis Pemetaan Lokasi Budidaya Tambak Ikan di Dinas Perikanan dan Kelautan Kabupaten Langkat Menggunakan Metode Clustering," J. Informatka Kaputama, vol. 1, no. 2, pp. 6-16, 2017.

[12] I. Fauzi, R. Alamsyah, A. T. A. R. Zulkifli, and A. Permatasari, "Studi Pemetaan Kawasan Tambak Kecamatan Sinjai Timur Dengan Menggunakan Penginderaan Jauh Dan Sistem Informasi Geografis," Agrominansia, vol. 3, no. 2, pp. 55-61, 2019, doi: 10.34003/271970.

[13] M. Abbasi, M. S. Pishvaee, and S. Bairamzadeh, "Land suitability assessment for Paulownia cultivation using combined GIS and Z-number DEA: A case study," Comput. Electron. Agric., vol. 176, p. 105666, Sep. 2020, doi: 10.1016/J.COMPAG.2020.105666.

[14] S. Saihu, "The Effect of Using Talking Stick Learning Model on Student Learning Outcomes in Islamic Primary School of Jamiatul Khair, Ciledug Tangerang," Tarbawi J. Keilmuan Manaj. Pendidik., vol. 6, no. 01, pp. 61-68, 2020, doi: 10.32678/tarbawi.v6i01.2325.

[15] dan H. R. Kasianus Kelvin Tanga, Maritha NilamKusuma, Musarofa, "Proses filtrasi dan dispersi jenis tanah sandy loam pada pengolahan air sungai," Pros. Semin. Teknol. Kebumian dan Kelaut., vol. 2, no. 1, pp. 1-4, 2018.

[16] A. I. Riza, "Aplikasi Sistem Informasi Geografis dalam Penentuan Kesesuaian Lokasi Perikanan Budidaya Tambak Ramah Lingkungan di Kabupaten Batang," RISTEK J. Riset, Inov. dan Teknol., vol. 1, no. (1), pp. 17-31, 2016. 